\title{
ANALISIS EFEKTIVITAS DAN KONTRIBUSI BEA PEROLEHAN HAK ATAS TANAH DAN BANGUNAN (BPHTB) TERHADAP PENDAPATAN ASLI DAERAH (PAD) PADA BADAN PENGELOLAAN PAJAK DAN RETRIBUSI DAERAH KOTA MANADO
}

\author{
Junisa Mandagi ${ }^{1}$, Harijanto Sabijono ${ }^{2}$, Stanley Kho Walandouw ${ }^{3}$ \\ 1,2,3 Jurusan Akuntansi, Fakultas Ekonomi dan Bisnis, Universitas Sam Ratulangi, Jl. Kampus Bahu, Manado, \\ 95115, Indonesia
}

Email : junisamandagi786@gmail.com

\begin{abstract}
The land and building title transfer duty is one of the regional tax that has large contribution as the receiver of the original local government revenue.One measure of the ability of regions to exploit the income is how much the local tax sector contributes to local revenues, especially local revenues that can later be used as a source of funds / expenses to meet the needs of local spending concerned. The purpose of this research is to know the affectiveness and the contribution of the land and building title transfer duty in manado city. The method that is used in this research is descriptive with using qualitative approach. Based on the result of this research, it shows that the effectiveness of the land and building title transfer duty in 2014-2017 is rated quite effective, while in 2016 it was decreasing in the percentage, on the other hand, the contribuction of the land and building title transfer duty in original local government revenue was unstable from year to year.
\end{abstract}

Keywords: Effectiveness, Contribution, Land and Building Title Transfer Duty, Original Local Government Revenue.

\section{PENDAHULUAN}

Indonesia pada saat ini memasuki era otonomi daerah, telah ada undang-undang pajak daerah dan retribusi daerah, undang-undang pemerintah daerah dan otonomi daerah, serta undang-undang perimbangan keuangan pusat dan daerah. Pelaksanaan pemungutan BPHTB diindikasikan bahwa masih ada wajib pajak yang belum mengetahui pengenaan BPHTB atas perolehan atau peralihan tanah dan bangunan. Masyarakat cenderung mengetahui adanya pengenaan BPHTB atas perolehan atau peralihan hak atas tanah dan bangunan ini dari pihak notaris/PPAT. Padahal dalam pemungutan BPHTB ini menganut self assesment system, dimana suatu sistem pemungutan pajak yang memberikan kepercayaan dan tanggung jawab kepada wajib pajak untuk menghitung, menyetor, dan melaporkan sendiri pajak terutang. Undang-undang Nomor 28 Tahun 2009 tentang Pajak Daerah dan Retribusi Daerah, salah satu jenis pajak pusat yang dialihkan menjadi pajak daerah adalah bea perolehan hak atas tanah dan bangunan (BPHTB). Kebijakan pengalihan BPHTB menjadi pajak daerah yang mulai efektif berlaku sejak 1 Januari 2011. Pengalihan BPHTB dari pajak pusat menjadi pajak daerah merupakan langkah strategis dalam pelaksanaan desentralisasi fiskal di Indonesia (Soewardi, 2014). Selaras dengan adanya salah satu tujuan desentralisasi fiskal, yaitu local taxing power, maka pemerintah daerah juga dituntut untuk menggali sumber dana dari pajak daerah, salah satunya adalah pajak bea perolehan hak atas tanah dan bangunan (BPHTB).

Banyaknya jumlah transaksi dalam jual beli tanah dan bangunan di Kota Manado, membuat wajib pajak tidak menyetorkan bea perolehan dari jual beli tanah dan bangunan sesuai dengan harga tanah dan bangunan yang akan dijual. Hal ini diketahui dari adanya beberapa notaris yang memalsukan bukti pembayaran dari nilai perolehan objek bea 
perolehan yang tidak sesuai, sehingga ini menyebabkan penyetoran bea perolehan yang seharunya banyak tapi kurang sehingga tidak efektif dalam kontribusinya terhadap penerimaan pajak daerah. Sehingga ini mengurangi penerimaan pajak daerah yang seharusnya bea perolehan hak atas tanah dan bangunan bisa memberi kontribusi yang lebih besar.

\section{TINJAUAN PUSTAKA}

\subsection{Akuntansi}

Akuntansi adalah salah satu jenis informasi yang penting bagi pengambilan keputusan baik didalam maupun diluar organisasi (Kinney yang dikutip oleh Chakraborty 2015). Sujawerni (2015 : 3) menyatakan bahwa akuntansi adalah proses dari transaksi yang dibuktikan dengan faktur, lalu dari transaksi dibuat jurnal, buku besar, neraca lajur, kemudian akan menghasilkan informasi dalam bentuk laporan keuangan yang digunakan pihak-pihak tertentu. Akuntansi dapat dipandang secara sempit sebagai suatu proses atau kegiatan yang meliputi proses pengidentifikasian, pengukuran, pencatatan, pengklasifikasian, penguraian, penggabungan, pengikhtisarian, dan penyajian data keuangan dasar yang terjadi sebagai dari kegiatan operasi suatu unit organisasi dengan cara-cara tertentu untuk menghasilkan informasi yang relevan bagi pihak yang berkepentingan (Lubis $2014: 3$ ).

\subsection{Pajak}

Pajak sebagai suatu kewajiban menyerahkan sebagian daripada kekayaan kepada negara disebabkan suatu kejadian dan perbuatan yang memberikan kedudukan tertentu, tetapi bukan sebagai hukuman, menurut peraturan-peraturan yang ditetapkan pemerintah serta dapat dipaksakan, tetapi tidak ada jasa balik dari negara secara langsung, untuk memelihara kesejahteraan umum (Djajadiningrat dalam buku Muljono 2015 : 1).

\subsection{Pajak Daerah}

Menurut Siahaan (2013:9) menyatakan bahwa pajak daerah merupakan pajak yang ditetapkan oleh pemerintah daerah dengan peraturan daerah (perda), yang wewenang pemungutannya dilakukan oleh pemerintah daerah dan hasilnya digunakan untuk membiayai pengeluaran pemerintah daerah dalam melaksanakan penyelenggaraan pemerintah dan pembangunan di daerah.

\subsection{Pajak Bea Perolehan Hak atas Tanah dan Bangunan}

Priantara (2013 : 584) menyatakan bahwa bea perolehan hak atas tanah dan bangunan (BPHTB) adalah pajak yang dikenakan atas perolehan hak atas tanah dan atau bangunan. Hak atas tanah dan bangunan termasuk hak pengelolaan, beserta bangunan diatasnya.

\subsubsection{Dasar Hukum Bea Perolehan Hak atas Tanah dan Bangunan}

Mardiasmo (2016 : 414) menyatakan bahwa dasar hukum bea perolehan hak atas tanah dan bangunan adalah : Undang-undang nomor 21 tahun 1997 sebagaimana telah diubah dengan undang-undang nomor 20 tahun 2000 tentang bea perolehan hak atas tanah dan bangunan. undang-undang ini menggantikan ordonansi bea balik nama staatsblad 1924 nomor 291 dan diubah dengan Undang-undang nomor 28 tahun 2009 tentang Pajak Daerah dan Retribusi Daerah.

\subsubsection{Objek Pajak}

Mardiasmo (2016 : 414 - 415) menyatakan bahwa objek BPHTB adalah perolehan hak atas tanah dan atau bangunan. Perolehan hak atas tanah dan atau bangunan dapat disebabkan karena pemindahan hak berupa jual-beli, tukar-menukar, hibah, hibah wasiat, waris, pemasukan dalam perseroan, pemisahan hak yang mengakibatkan peralihan, penunjukan pembeli dalam lelang, pelaksanaan keputusan hakim, penggabungan usaha, peleburan usaha, pemekaran usaha, dan hadiah. 


\subsubsection{Tidak termasuk objek pajak}

Mardiasmo (2016 : 415) menyatakan bahwa objek pajak yang tidak dikenakan BPHTB adalah objek pajak yang diperoleh : 1.perwakilan diplomatik; 2. negara untuk penyelenggaraan pemerintahan dan atau pelaksanaan pembangunan guna kepentingan umum; 3. badan atau perwakilan organisasi internasional yang ditetapkan dengan keputusan menteri dengan syarat tidak menjalankan usaha atau melakukan kegiatan lain diluar fungsi dan tugas badan usaha atau perwakilan organisasi tersebut; 4 . badan atau orang pribadi konversi hak; 5 . badan atau orang pribadi karena wakaf; dan 6 . orang pribadi atau badan untuk kepentingan ibadah.

\subsubsection{Jenis Hak Atas Tanah Pada Perolehan Hak}

Priantara (2013 : 685) menyatakan bahwa sesuai dengan undang-undang nomor 5 tahun 1960 tentang peraturan dasar pokok-pokok agraria, dan undang-undang nomor 16 tahun 1985 tentang rumah susun, hak atas tanah adalah : 1. hak milik; 2. hak guna usaha; 3. hak guna bangunan; 4. hak pakai; 5. hak milik atas satuan rumah susun; dan 6. hak pengelolaan.

\subsubsection{Subjek Pajak Dan Wajib Pajak}

Mardiasmo (2016 : 416) menyatakan bahwa subjek pajak BPHTB adalah orang pribadi atau badan yang memperoleh hak atas tanah dan atau bangunan. Wajib pajak BPHTB adalah orang pribadi atau badan yang memperoleh hak atas tanah dan atau bangunan.

\subsubsection{Dasar Pengenaan Pajak}

Mardiasmo (2016 : 416) menyatakan bahwa yang menjadi dasar pengenaan pajak adalah nilai perolehan objek pajak (NPOP) ditentukan sebesar :

1. Harga transaksi, dalam hal jual beli.

2. Nilai pasar objek pajak, dalam hal : a. tukar-menukar; b. hibah; c. hibah wasiat; d. waris; e. pemasukan dalam perseroan; f. pemisahan hak mengakibatkan peralihan hak; g. pemberian hak baru atas tanah sebagai kelanjutan dari pelepasan hak; h. pemberian hak baru atas tanah; i. penggabungan usaha; j. peleburan usaha; k. pemekaran usaha; 1. hadiah.

3. Harga transaksi yang tercantum dalam risalah lelang, dalam hal penunjuk pembeli dalam lelang.

4. Nilai jual objek pajak pajak bumi dan bangunan (NJOP PBB), apabila besarnya NPOP sebagaimana dimaksud dalam poin 1 dan 2 tidak diketahui atau NPOP lebih rendah dari pada NJOP PBB.

\subsubsection{Nilai Perolehan Objek Pajak Tidak Kena Pajak (NPOPTKP)}

Besarnya NPOPTKP ditetapkans ecara regional paling rendah Rp 60.000.000,00 (enam puluh juta rupiah), kecuali dalam hal perolehan hak karena waris, atau hadiah wasiat yang diterima orang pribadi yang masih dalam hubungan keluarga sedarah dalam garis keturunan lurus satu derajat ke atas atau satu derajat kebawah dengan pemberi hibah wasiat, termasuk suami/istri, nilai perolehan objek wajib pajak tidak kena pajak ditetapkan secara regional paling rendah Rp 300.000.000.00 (tiga ratus juta rupiah). Besarnya NPOPTKP ditetapkan dengan peraturan daerah.

\subsubsection{Tarif Pajak}

Besarnya tarif pajak ditetapkan sebesar paling tinggi sebesar 5\% (lima persen). tarif bea perolehan hak atas tanah dan bangunan ditetapkan dengan peraturan daerah. Cara menghitung BPHTB :

$$
\text { BPHTB }=(\text { NPOP }- \text { NPOPTKP }) \times 5 \%
$$




\subsubsection{Saat Dan Tempat Pajak Yang Terutang}

Mardiasmo (2016 : 418) menyatakan bahwa saat yang menentukan terutangnya pajak adalah :

1. Sejak tanggal dibuat dan ditandatanganinya akta, untuk : a. jual-beli; b. tukar-menukar; c. hibah; d. hibah wasiat; e. pemasukan dalam perseroan atau badan hukum lainnya; f. pemisahan hak yang mengakibatkan peralihan; g. penggabungan usaha; h. peleburan usaha; i. pemekaran usaha; j. hadiah.

2. Sejak tanggal penunjukan untuk lelang.

3. Sejak tanggal putusan pengadilan untuk: putusan hakim

4. Sejak tanggal yang bersangkutan untuk hibah wasiat dan waris

5. Sejak tanggak ditandatangani dan diterbitkannya surat keputusan pemberian hak, untuk : a. pemberian hak baru atas tanah sebagai kelanjutan dari pelepasan hak; dan b.pemberian hak baru diluar pelepasan hak.

\subsection{Pendapatan Asli Daerah}

Menurut Siahaan (2013 : 11), pajak dan retribusi daerah adalah sumber penerimaan daerah telah dipungut sejak awal kemerdekaan Indonesia. Sumber penerimaan ini terus dipertahankan sampai dengan era otonomi daerah dewasa ini. Penetapan pajak dan retribusi daerah sebagai sumber penerimaan daerah ditetapkan dengan dasar hukum yang kuat, yaitu dengan undang-undang, khususnya undang-undang tentang pemerintahan daerah maupun tentang perimbangan keuangan antara pusat dan daerah.

\subsubsection{Langkah-Langkah Meningkatkan PAD}

Dalam penelitian Eno Suhendi (2012) dikutip bahwa, upaya untuk meningkatkan pendapatan asli daerah (PAD) merupakan tugas berat yang mau tidak mau harus dilakukan oleh setiap daerah setelah berlakunya UU tentang otonomi daerah. Ada beberapa kebijakan umum yang bisa diterapkan di berbagai daerah dalam upaya meningkatkan pendapatan asli daerah (PAD) yaitu :

1. Memperluas basis penerimaan daerah. Untuk perluasan basis ini maka langkah yang perlu di tempuh adalah :

a. Melakukan pendapatan wajib pajak/retribusi bari yang potensial.

b. Memperbaiki basis data objek pajak/retribusi dengan jalan membentuk team untuk memperbaharui jumlah pembayaran pajak/retribusi di daerah masing-masing.

c. Memperbaiki penilaian kembali objek pajak.

d. Menghitung kapasitas penerimaan (potensi) setiap jenis pungutan.

e. Melakukan pelatihan terhadap staf keuangan.

2. Meningkatkan pengawasan untuk mengurangi kebocoran. Untuk itu diperlukan tindakan sebagai berikut :

a. Pemeriksaan mendadak untuk melengkapi prosedur pemungutan self assessment.

b. Memperbaiki proses pengawasan.

c. Upaya untuk menerapkan sanksi yang berat dan ketat bagi para penunggak.

d. Menerapkan disiplin administrasi bagi staf keuangan yang memberikan kontribusi terhadap kebocoran penerimaan daerah.

e. Upaya untuk mengaitkan pembayaran pajak/retribusi dengan pelayanan yang diberikan oleh pemerintah daerah. Hal ini dilakukan dalam rangka meningkatkan kesadaran membayar pajak untuk mengurangi penunggak dan penghindaran pungutan.

3. Meningkatkan efisiensi administrasi untuk mengurangi berbagai pungutan. Ini merupakan bagian dari upaya untuk meminimalkan biaya pemungutan. Langkah yang dapat dilakukan antara lain melalui penyederhanaan administrasi, menghitung tingkat efisiensi pemungutan setiap penerimaan, mengurangi biaya pemungutan, dan menghilangkan 
faktor-faktor yang teridentifikasi dilapangan yang memberikan kontribusi terhadap kurang optimalnya penerimaan.

\subsubsection{Efektivitas}

Efektivitas secara umum merupakan suatu ukuran sampai seberapa jauh tercapainya suatu tujuan yang sebelumnya telah ditargetkan. Ulum (2012 : 31) menyatakan bahwa efektivitas adalah ukuran berhasil tidaknya suatu organisasi mencapai tujuannya. Apabila suatu organisasi berhasil mencapai tujuan, maka organisasi tersebut dikatakan telah berjalan.

\subsubsection{Kontribusi}

Kontribusi digunakan untuk mengetahui sejauh mana Bea Perolehan Hak atas Tanah dan Bangunan memberikan sumbangan dalam pendapatan asli daerah. Kontribusi adalah sumbangan atau sesuatu kegiatan yang diberikan terhadap suatu kegiatan sehingga memberikan dampak yang bisa dirasakan (Fauziah, dkk. 2014).

\subsection{Penelitian Terdahulu}

Julianti (2016) dalam penelitian Analisis Efektivitas dan Kontribusi Penerimaan Bea Perolehan Hak atas Tanah dan Bangunan Terhadap Pendapatan Asli Daerah Kota Kotamobagu. Hasil penelitian menunjukan bahwa penerimaan bea perolehan hak atas tanah dan bangunan dalam 4 tahun terakhir sudah sangat efektif. Secara keseluruhan kontribusi bea perolehan hak atas tanah dan bangunan tahun anggaran 2012-2015 memberikan kontribusi yang baik terhadap PAD.

Absor Manossoh (2017) dalam penelitian Analisis Efektivitas dan Kontribusi Bea Perolehan Hak atas Tanah dan Bangunan di Kabupaten Minahasa Utara. Hasil penelitian menunjukan bahwa di kabupaten minahasa utara tingkat efektivitas tahun anggaran 20132016 dinilai sangat efektif walaupun ditahun 2015 mengalami penurunan dalam persentase sedangkan kontribusi BPHTB pada pendapatan asli daerah tidak stabil dari tahun ke tahun.

\section{METODE PENELITIAN}

\subsection{Jenis Penelitian}

Penelitian ini menggunakan penelitian deskriptif dengan pendekatan kualitatif. Penelitian deskriptif kualitatif adalah penelitian yang dilakukan untuk menilai satu variabel atau lebih sifatnya independen dengan tidak ada hubungan maupun perbandingan dengan variabel lain.

\subsection{Tempat dan Waktu Penelitian}

Penelitian ini dilakukan pada Badan Pengelolaan Pajak dan Retribusi Daerah Kota Manado, yang berkedudukan di Jl. Balaikota 1, Tikala Kumaraka, Wenang, Kota Manado, Sulawesi Utara, Indonesia. Telp. (0431) 364143. Penelitian ini dilakukan selama 2 sampai 3 bulan.

\subsection{Prosedur Penelitian}

Adapun keterangan yang di lakukan dari tahap-tahap Prosedur Penelitian di atas adalah sebagai berikut.: 1 . memasukan surat permohonan; 2 . pengumpulan data; 3 . analisis data penelitian; dan 4. kesimpulan dan saran.

\subsection{Metode Pengumpulan Data}

\subsubsection{Jenis Data}

1. Data Kualitatif adalah data yang menggunakan deskripsi prosedur secara naratif, ungkapan atau pernyataan dan menyimpulkan hasil secara naratif.

2. Data Kuantitatif adalah reduksi data menjadi angka-angka dan menyimpulkan hasil menggunakan statistik.

\subsubsection{Sumber Data}

1. Data Primer yaitu data yang diperoleh dari responden melalui hasil wawancara peneliti dengan narasumber. 
2. Data Sekunder yaitu data yang didapat dari caatan, buku, majalah berupa laporan keuangan publikasi perusahaan, artikel dan buku-buku sebagai teori.

\subsection{Teknik Pengumpulan Data}

Teknik pengumpulan data di lakukan dengan 3 cara, yaitu : 1. penelitian lapangan (field research); 2. wawancara (interview); dan 3. peninjauan langsung (observation).

\subsection{Metode Analisis}

Metode analisis data yang digunakan dalam penelitian ini adalah menggunakan metode analisis deskriptif kualitatif, yaitu dengan cara menggambarkan kenyataan atau keadaan-keadaan atas suatu objek dalam bentuk uraian kalimat, data angka berdasarkan keterangan-keterangan dari pihak-pihak yang berhubungan langsung dengan penelitian ini. Metode analisis ini digunakan untuk mendeskripsikan bagaimana efektivitas dan kontribusi BPHTB pada Dinas Pengelolaan Pajak dan Retribusi Daerah Kota Manado.

\subsection{Analisis Efektifitas}

Untuk mengklasifikasikan kriteria efektivitas BPHTB terhadap Pendapatan Daerah digunakan rumus sebagai berikut :

$$
\text { Efektifitas }=\frac{\text { Realisasi BPHTB }}{\text { Target BPHTB }} \times 100 \%
$$

\subsection{Analisis Kontribusi}

Untuk mengklasifikasikan kriteria kontribusi BPHTB terhadap Pendapatan Daerah digunakan rumus sebagai berikut :

$$
\text { Kontribusi }=\frac{\text { Realisasi BPHTB }}{\text { Realisasi PAD }} \text { X100\% }
$$

\section{HASIL PENELITIAN DAN PEMBAHASAN}

\subsection{Hasil Penelitian}

\subsubsection{Pendapatan Asli Daerah Kota Manado}

Pendapatan Asli Daerah Kota Manado terdiri dari sumber-sumber penerimaan sebagai berikut :

1. Pajak Daerah

2. Retribusi Daerah

3. Hasil Pengelolaan Kekayaan Daerah yang dipisahkan

4. Lain-lain pendapatan asli daerah yang sah

Dari ke empat sumber penerimaan tersebut maka terbentuknya Pendapatan Asli Daerah Kota Manado sebagai berikut :

Tabel 4.1

Target dan Realisasi Pendapatan Asli Daerah Kota Manado TA 2014-2017

\begin{tabular}{|c|c|c|r|}
\hline Tahun & $\begin{array}{c}\text { Target PAD } \\
(\mathbf{R p})\end{array}$ & $\begin{array}{c}\text { Realisasi PAD } \\
\text { (Rp) }\end{array}$ & Persentase \\
\hline 2014 & $257,771,320,560$ & $263,392,296,958$ & $102.18 \%$ \\
\hline 2015 & $273,391,133,000$ & $289,462,741,463$ & $105.88 \%$ \\
\hline 2016 & $288,228,847,854$ & $306,453,382,648$ & $106.32 \%$ \\
\hline 2017 & $363,796,582,200$ & $352,873,841,440$ & $97.00 \%$ \\
\hline
\end{tabular}

Sumber data : Badan Pengelola dan Retribusi Daerah Kota Manado (2018) 


\subsubsection{Target dan Realisasi BPHTB Kota Manado}

Tabel 4.2

Target dan Realisasi BPHTB Kota Manado TA 2014-2017

\begin{tabular}{|c|c|c|r|}
\hline Tahun & Target (Rp) & Realisasi (Rp) & \multicolumn{1}{c|}{ Persentase } \\
\hline 2014 & $45,675,000,000$ & $38,091,090,108$ & $83.40 \%$ \\
\hline 2015 & $45,675,000,000$ & $40,580,747,667$ & $88,85 \%$ \\
\hline 2016 & $41,576,000,000$ & $28,630,670,885$ & $68.86 \%$ \\
\hline 2017 & $34,200,000,000$ & $52,006,275,741$ & $152.07 \%$ \\
\hline
\end{tabular}

Sumber data : Badan Pengelola dan Retribusi Daerah Kota Manado (2018)

\subsection{Pembahasan}

\subsubsection{Analisis Rasio Efektivitas Bea Perolehan Hak atas Tanah dan Bangunan}

1. Tahun 2014

Berdasarkan target penerimaan Bea Perolehan Hak atas Tanah dan Bangunan Rp. 45.675.000.000 dengan realisasi yang diperoleh sebesar Rp. 38.091.090.108, maka efektivitas BPHTB tahun 2014 dapat diketahui dengan perhitungan sebagai berikut:

$$
\begin{aligned}
\text { Efektifitas } & =\frac{\text { Rp. 38.091.090.108 }}{\text { Rp. 45.675.000.000 }} \times 100 \% \\
& =83,40 \%
\end{aligned}
$$

Jadi tingkat efektivitas penerimaan BPHTB tahun 2014 sebesar 83,40\%

\section{Tahun 2015}

Berdasarkan target penerimaan Bea Perolehan Hak atas Tanah dan Bangunan Rp. 45.675.000.000 dengan realisasi yang diperoleh sebesar Rp. 40.580.747.667, maka efektivitas BPHTB tahun 2015 dapat diketahui dengan perhitungan sebagai berikut :

$$
\begin{aligned}
\text { Efektifitas } & =\frac{\text { Rp. } 40.580 .747 .667}{\text { Rp. 45.675.000.000 }} \times 100 \% \\
& =88,85 \%
\end{aligned}
$$

Jadi tingkat efektivitas penerimaan BPHTB tahun 2015 sebesar 88,85\%

3. Tahun 2016

Berdasarkan target penerimaan Bea Perolehan Hak atas Tanah dan Bangunan Rp. 41.576.000.000 dengan realisasi yang diperoleh sebesar Rp. 28.630.670.885, maka efektivitas BPHTB tahun 2016 dapat diketahui dengan perhitungan sebagai berikut:

$$
\begin{aligned}
\text { Efektifitas } & =\frac{\text { Rp. } 28.630 .670 .885}{\text { Rp. } 41.576 .000 .000} \times 100 \% \\
& =68,86 \%
\end{aligned}
$$

Jadi tingkat efektivitas penerimaan BPHTB tahun 2016 sebesar 68,86\%

4. Tahun 2017

Berdasarkan target penerimaan Bea Perolehan Hak atas Tanah dan Bangunan Rp.34.200.000.000 dengan realisasi yang diperoleh sebesar 52.006.275.741, maka efektivitas penerimaan BPHTB tahun 2017 dapat diketahui dengan perhitungan sebagai berikut: 


$$
\begin{aligned}
\text { Efektifitas } & =\frac{\text { Rp. 52.006.275.741 }}{\text { Rp.34.200.000.000 }} \times 100 \% \\
& =152,07 \%
\end{aligned}
$$

Jadi tingkat efektivitas penerimaan BPHTB tahun 2017 sebesar 152,07\%

Tabel 4.3

Efektifitas penerimaan BPHTB Kota Manado TA 2014-2017

\begin{tabular}{|c|c|r|r|l|}
\hline Tahun & $\begin{array}{c}\text { Target } \\
(\mathbf{R p})\end{array}$ & $\begin{array}{c}\text { Realisasi } \\
(\mathbf{R p})\end{array}$ & $\begin{array}{c}\text { Persentase } \\
\text { Efektivitas }\end{array}$ & \multicolumn{1}{c|}{$\begin{array}{c}\text { Kriteria } \\
\text { Efektivitas }\end{array}$} \\
\hline 2014 & $45,675,000,000$ & $38,091,090,108$ & $83.40 \%$ & Cukup efektif \\
\hline 2015 & $45,675,000,000$ & $40,580,747,667$ & $88.85 \%$ & Cukup efektif \\
\hline 2016 & $41,576,000,000$ & $28,630,670,885$ & $68.86 \%$ & Kurang efektif \\
\hline 2017 & $34,200,000,000$ & $52,006,275,741$ & $152.07 \%$ & Sangat efektif \\
\hline
\end{tabular}

Sumber data : Badan Pengelola dan Retribusi Daerah Kota Manado (2018)

Tabel 4.3 dapat dilihat tingkat efektifitas penerimaan BPHTB Kota Manado pada tahun 2014-2016 tidak mencapai target, sedangkan pada tahun 2017 mencapai target yang ditentukan daerah. Pada tahun 2014 sebesar $83.40 \%$, sehingga dikategorikan "cukup efektif", tahun 2015 sebesar $88.85 \%$, sehingga dikategorikan "cukup efektif", tahun 2016 sebesar $68.86 \%$, sehingga dikategorikan "kurang efektif", tahun 2017 sebesar 152.07\%, sehingga dikategorikan "sangat efektif".

\subsubsection{Analisis Kontribusi Bea Perolehan Hak atas Tanah dan Bangunan}

1. Tahun 2014

$$
\begin{aligned}
\text { Kontribusi } & =\frac{\text { Rp.38.091.090.108 }}{\text { Rp. 263.392.296.958 }} \times 100 \% \\
& =14,46 \%
\end{aligned}
$$

Dari hasil perhitungan diatas dapat diperoleh penerimaan kontribusi BPHTB terhadap PAD Kota Manado pada tahun 2014 sebesar 14,46\%.

2. Tahun 2015

$$
\begin{aligned}
\text { Kontribusi } & =\frac{\text { Rp. 40.580.747.667 }}{\text { Rp. 289.462.741.463 }} \times 100 \% \\
& =14,01 \%
\end{aligned}
$$

Dari hasil perhitungan diatas dapat diperoleh penerimaan kontribusi BPHTB terhadap PAD Kota Manado pada tahun 2015 sebesar 14,01\%.

3. Tahun 2016

$$
\begin{aligned}
\text { Kontribusi } & =\frac{\text { Rp. 28.630.670.885 }}{\text { Rp. 306.453.382.648 }} \times 100 \% \\
& =9,34 \%
\end{aligned}
$$

Dari hasil perhitungan diatas dapat diperoleh penerimaan kontribusi BPHTB terhadap PAD Kota Manado pada tahun 2016 sebesar 9,34\%. 
4. Tahun 2017

$$
\begin{aligned}
\text { Kontribusi } & =\frac{\text { Rp. 52.006.275.741 }}{\text { Rp. 352.873.841.440 }} \times 100 \% \\
& =14,73 \%
\end{aligned}
$$

Dari hasil perhitungan diatas dapat diperoleh penerimaan kontribusi BPHTB terhadap PAD Kota Manado pada tahun 2017 sebesar 14,73\%.

Berdasarkan perhitungan diatas dapat diketahui berapa besar kontribusi Bea Perolehan Hak atas Tanah dan Bangunan terhadap PAD kota Manado untuk anggaran 20142017 , untuk lebih jelasnya dapat dilihat pada tabel berikut ini:

Tabel 4.4

Kontribusi BPHTB terhadap PAD Kota Manado TA 2014-2017

\begin{tabular}{|c|c|r|r|l|}
\hline Tahun & $\begin{array}{c}\text { BPHTB } \\
(\mathbf{R p})\end{array}$ & $\begin{array}{c}\text { PAD } \\
\text { (Rp) }\end{array}$ & \multicolumn{1}{|c|}{ Kontribusi } & \multicolumn{1}{|c|}{ Kriteria } \\
\hline 2014 & $38,091,090,108$ & $263,392,296,958$ & $14.46 \%$ & Kurang baik \\
\hline 2015 & $40,580,747,667$ & $289,462,741,463$ & $14.01 \%$ & Kuran baik \\
\hline 2016 & $28,630,670,885$ & $306,453,382,648$ & $9.34 \%$ & Sangat kurang \\
\hline 2017 & $52,006,275,741$ & $352,873,841,440$ & $14.73 \%$ & Kurang baik \\
\hline
\end{tabular}

Sumber data : Badan Pengelola dan Retribusi Daerah Kota Manado (2018)

Tabel 4.4 dapat diketahui kontribusi Bea Perolehan Hak atas Tanah dan Bangunan terhadap Pendapatan Asli Daerah di Kota Manado pada tahun 2014 sebesar 14.46\% dengan kriteria "kurang baik", tahun 2015 sebesar 14.01\% dengan kriteria "kurang baik", tahun 2016 sebesar 9.34\% dengan kriteria "sangat kurang", dan tahun 2017 sebesar 14.73\% dengan kriteria "kurang baik".

\section{KESIMPULAN DAN SARAN \\ 5.1. Kesimpulan}

1. Efektivitas BPHTB setiap tahunnya mengalami perubahan. Pada tahun 2014 efektivitas BPHTB mencapai 83,40\% , ditahun 2015 efektivitas BPHTB mengalami peningkatan menjadi 88,85\%, pada tahun 2016 efektivitas BPHTB mengalami penurunan menjadi 68,86\%, kemudian ditahun 2017 efekrivitas BPHTB kembali mengalami peningkatan menjadi $152,07 \%$. dengan melihat rata-rata efektivitas BPHTB Kota Manado yang melebihi 100\%, hal ini menunjukan bahwa kinerja efektivitas BPHTB kota manado kurang baik.

2. Pada tahun 2014 kontribusi BPHTB sebesar 14,46\% , pada tahun 2015 kontribusi BPHTB sebesar 14,01\% , pada tahun 2016 kontribusi BPHTB sebesar 9,34\%, pada tahun 2017 kontribusi BPHTB sebesar 14,73\%. Dapat dilihat bahwa kontribusi BPHTB dikota Manado kurang baik.

\subsection{Saran}

1. Melaksanakan penyuluhan kepada masyarakat dengan pihak-pihak yang terkait mengenai informasi tentang perpajakan terbaru, sehingga dapat diharapkan pengertian dan kesadaran masyarakat tentang pajak semakin meningkat.

2. Meningkatkan kualitas dan kuantitas dari sumber daya manusia seperti pemeriksaan pajak dengan memberikan kompensasi dan intensif yang mencukupi agar supaya kinerja pemeriksa dalam melaksanakan pemeriksaan bisa lebih optimal.

3. Transparansi dalam proses pelaksanaan tugas dan penggunaan pajak sehingga dapat diharapkan antusias yang baik dari masyarakat dalam membayarkan pajak. 


\section{DAFTAR PUSTAKA}

Absor, Manossoh dan Mawikere, 2017. Analisis Efektivitas dan Kontribusi Bea Perolehan Hak atas Tanah dan Bangunan di Kabupaten Minahasa Utara.

Chakraborty A. 2015. Impact of Poor Accounting Practices on the Growth and Sustainability of SME's.

Julianti, 2016. Analisis Efektivitas dan Kontribusi Penerimaan Bea Perolehan Hak atas Tanah dan Bangunan Terhadap Pendapatan Asli Daerah Kota Kotamobagu.

Lubis, Arfan Ikhsan. 2014. Akuntansi Keperilakuan. Edisi 2. Salemba Empat, Jakarta.

Mardiasmo, 2016. Perpajakan. Edisi Terbaru 2016. Penerbit Andi. Yogyakarta.

Muljono Djoko, 2015. Hukum Pajak. Penerbit Andi. Yogyakarta.

Priantara Diaz, 2013. Perpajakan Indonesia. Edisi 2 Revisi. Penerbit Mitra Wacana Media. Jakarta.

Siahaan Marihot, 2013. Pajak Daerah dan Retribusi Daerah. Edisi Revisi. PT. Raja Grafindo Persada. Jakarta.

Suhendi Eno, 2012. Analisis Faktor-Faktor Yang Mempengaruhi Penerimaan Pajak Hotel dan Restoran di Kota Yogyakarta.

Sujawerni V. Wiratna, 2015. Sistem Akuntansi. Pustaka Baru Press, Yogyakarta.

Syarief Fauzie, 2016. Factors Affecting Duty Acquisition Of Rights To Land and Building With Economic Growth As The Mediating Variable in Indonesia.

Ulum Ihyaul, 2012. Audit Sektor Publik. Jakarta: Bumi Aksara. 